\title{
A Study on the Correlation of the Remittances and the Life of the Albanian Families
}

\author{
Teuta Thanasi \\ "Aleksandër Moisiu" University, Durrës, Albanıa \\ teutamatematika@hotmail.com \\ Robert Kosova \\ "Aleksandër Moisiu" University, Durrës, Albanıa \\ robertko60@yahoo.com \\ Lindita Mukli
}

Aleksandër Moisiu" University, Durrës, Albania Dean of the Faculty of Information Technlogy mukli_lindita@yahoo.com

\section{Doi:10.5901/ajis.2014.v3n2p347}

\section{Abstract}

Our study focuses on the late trend of remittances in Albania and their correlation to the everyday life of the Albanian families. In order to come to our conclusions we have extensively made use of field studies and we have heavily relied on questionnaires and the date acquired through them. Nowadays the remittances are quite important to most of Albanian families. The fact that there are few Albanian families not benefiting in this or that way from remittances is another indication on their impact on the daily life of the Albanians. We made use of a three chapters questionnaire. They were used to bring us as much info as possible. More data to process will help us to come to sounder scientific conclusions. The data show the vast extension of remittance phenomenon and them being still important to the family budget. The data received from the questionnaire show also the remittances are feeling the pinch due to the economic crises hitting Greece and Italy, such an effect is coupled with the remittance cycle, too. In a nut shell, remittances do not consist any more the most precious "gem" in Albanians "coffers". The remittances make their presence felt on the family business, too. Yet they can not replace or mitigate the fall in FDI(Foreign Direct Investments), as they consist of little amounts of money ramificated to a vast number of families, meaning too little to be an investment, too small to cause an impact. Only the money brought home by our migrants returning home for good from Greece and Italy due to the crises there can save as a sort of special FDI. Yet this is a one time act not a continuous flow as in the case of remittances.

Keywords: remittance, savings, migrants, questionnaire, crises.

\section{Introduction}

Taking into consideration the reports of such important institutions like World Bank or The Bank of Albania we can safely state that the remittances and FDI still remain the two most powerful engines driving forward the Albanian economy. Presently they weigh heavier than foreign loans, grants and financial aid. Their correlation to sustained economic growth is crucial as they are the largest and the only continuous source of hard currency and capital.

Let us have a look at the remittances. In 20003 it was 100 billion USD the world wide flow of remittances. Some $60 \%$ of such a flow is directed to the developing countries. The Global Development Finance- 2003 Report issued by the World Bank offers such figures. Up to 2006 the amount of hard currency gained by exports, FDI-s and foreign aid amounted to less than the remittances entering Albania. Precisely these are the figures supplied by The Bank of Albania, by INSTA( Albanian Institute of Statistics) and by IOM. Thus we can safely assert that Albania is an example of the importance of the remittances in transferring resources (i.e hard currency) from developed countries to developing ones.

\section{Remittances from 19991 to 2002}

The share of the remittances keeps increasing in Albanian PBB. Its share goes from 10-22\% of Albanian PBB. In 2001 we had 443 million Euro in remittances i.e.15\% of PBB, while in 1992 it was only 107 Euro(Marks, Liras, Franks etc.) or 
$22 \%$ of PBB. Anyway the remittances were of secondary importance compared to foreign food aid which helped us avoid a famine in Albania.

\section{Graphics 1.}

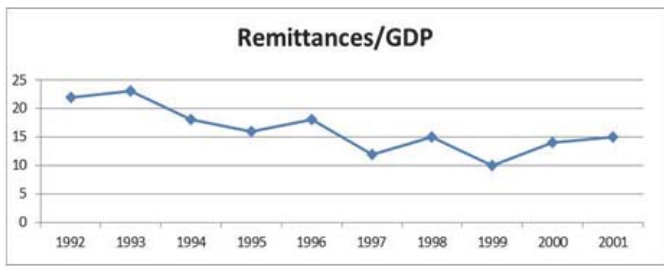

The ratio of remittances to the foreign aid and the FDI is another aspect of the importance of the remittances. Judging by the figures offered by the Annual Report of The Bank of Albania covering the period 1992-2001 we see that the remittance money (3924,2 million USD) is five times bigger than the FDI influx (just 774,7 million USD).In 2001 the foreign aid to Albania amounted to 180 million USD, while the remittances were 3,4 times higher in the same year.

Graphics 2. The dynamics of remittances, exports and FDI in the period 1992-2001

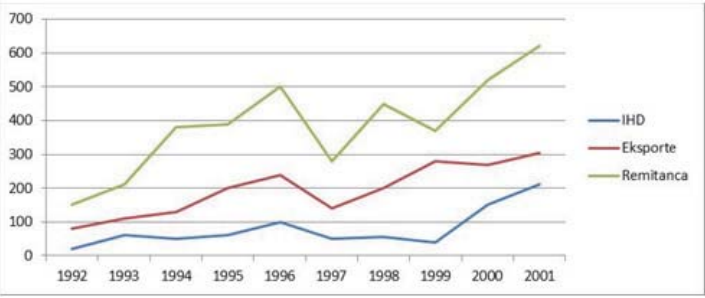

Now let us tackle the ratio of remittances to exports and their contribution to the economic growth in my country. In 2001 the remittance money was twice the hard currency earned from the Albanian exports. It was some 200 USD per capita. This figure shows that the remittances were the chief fancier of Albanian imports and instrument in covering the trade deficit. These remittances kept the exchange rate of the Albanian currency Lek stable, too. The remittances had their lion's share in financing the growth of the construction and service sectors of the Albanian economy.

Graphics 3. The dynamics of the remittances, imports, exports and the trade deficit in the period 1992-2001.

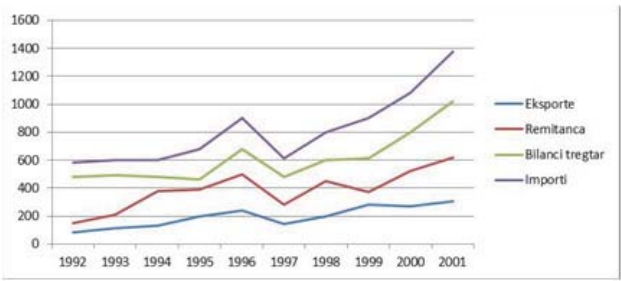

Judging by these data we conclude that the remittances were an important factor in shaping one of the peculiar characteristics of the transition of the economy of Albania, the phenomenon of the extroversion, meaning the inner consumption in my country was bigger than the PBB the economy could generate at that period of time.

\section{The Remittance Trend in the Last Five Years, and Related Conclusions}

The crises in Greece an Italy did affect remittances, too. Less money earned meant less remittances home. This is the trend of the last five years. Such a fall meant also a change in the ratio of the remittances to exports and FDI. The Annual 
Report of The Bank of Albania records such shrinking remittance. What was the source of the money covering the missing remittances? There were two sources.

1. An increase in Albanian exports due to favorable prices on the world market for typical Albanian export goods such as chromium, pig iron, steel. The rainy winter of 2010-2011, positively affected the Albanian export of renewable energy(from the hydropower stations). The spring of 2013 fortunately was also a very wet one, too.

2. The second source was the increased FDI. They were not coming from a few big strategic investments but in the form of thousands of returned Albanian migrants returning home, bringing their life savings with them, investing these savings in their home country. Such investments generally are in the service sector in the form of the self employment, or in the form of family business.

Let us have an analyses the figures in the following table of the relative graphics. It shows the trend of the remittances of the last five years.

Table 1. Remittances in million Euro

\begin{tabular}{|c|c|c|c|c|c|}
\hline Year & $\mathbf{2 0 0 6}$ & $\mathbf{2 0 0 7}$ & $\mathbf{2 0 0 8}$ & $\mathbf{2 0 0 9}$ & $\mathbf{2 0 1 0}$ \\
\hline Remittance & 937,2 & 951,7 & 833,3 & 781,3 & 689,8 \\
\hline
\end{tabular}

Graphics 4. Remittances in million Euro

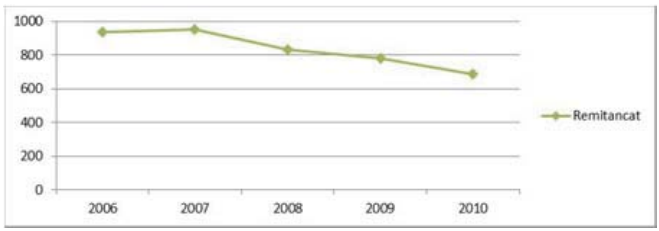

Source: Banka e Shqipërise ,Annual Report of the National Bank of Albania, 2012

These figures demonstrates the downward trend of the remittances as compared to a few years ago. In 2010 against the previous year we have a 91,5 million Euro deficit in the remittance balance as per the Report of The Bank of Albania. This deficit goes to 247,4 million Euro compared with 2006. Thus the downward trend is for a four years period.

In 2010 it was witnessed a 12\% drop compared to 2009 and a 29\% drop compared to 2006, serving thus as an illustration of the above conclusion.

\section{Processing the Questionnaires Data}

It was Durres District and the area nearby where our field work took place. It covered the flow of the remittances in several years up to 2006. The second part of our study deals with the comparison of these results with the late remittance trend based by the data of The Annual Report of The Bank of Albania. Questionnaire is our "tool" of research. We process the answers we obtained in our questionnaire in order to have answers to our questions.

$>$ What are the characteristics of the families of the interviewed persons and the influence of these characteristics on the earnings of their families and the quantity of remittances received by the family members?

$>$ What are these remittances used for?

$>$ How are the remittances transferred to Albania?

$>$ The frequency of the remittances.

$>$ Reasons behind the quantity of the received remittances

$>$ How much are the family savings?

$>$ What's the contribution of the remittances in these savings?

What are the savings used for and are they enough?

The survey took place from September 2012 to February 2013. A team of students from the Faculty of Economics at "Aleksander Moisiu" Durres University and the Faculty of Economics at Tirana University rendered a valuable contribution in implementing this survey. 
We proceeded like this; First a training session with the students concentrating on the content of the questionnaire and the best way in applying the survey in different families. We also assigned the areas of responsibility to each student. I took advantage of being a lecturer of mathematics, statistics and probability up at :Aleksander Moisiu" Durres University by implementing this questionnaire to the families of some of my students, too. They had a remittance sending migrant at least one of their family members. These students were trained first, then they answered the questions.

After the collection of the data from the questionnaire they were processed using mathematics and statistics methods resulting in :

\section{The Characteristics of the Families}

The results to the questions on the family members were as follows;

The majority of the families consisted of 4 to 5 members (34.5\% and $27.3 \%$ of the interviewed). Of interest is the rather high number of families with 6 members almost $15.5 \%$ of the total number. Thus generally we have a medium size family not an extended one. This is reflected on the following graphics

\section{Graphic 5.}

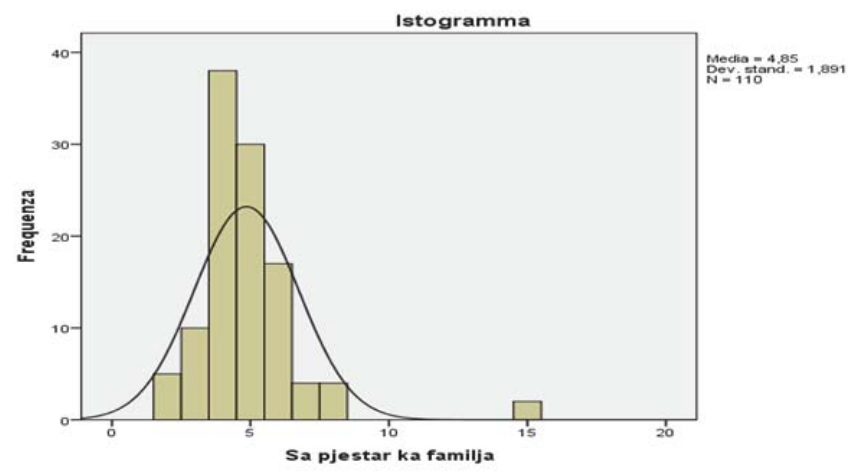

Question: Have you school attending children ? The answer was $40 \%$ no and a $60 \%$ yes. This question aims at understanding whether the fact of having school attending children is a reason of receiving remittances, or not.

Question: Is the head of the family a retired citizen or a working age one? 44\% were retired citizens. This is a high figure but also 58\% were employed and only $8 \%$ were unemployed.

Unfortunately a large number of families still need the remittances to go by, though the head of the family is not unemployed. This is a direct result of the economic crises in the host countries, its effect on the earnings of the migrants, and their ability to save money.

\section{Graphics 6.}

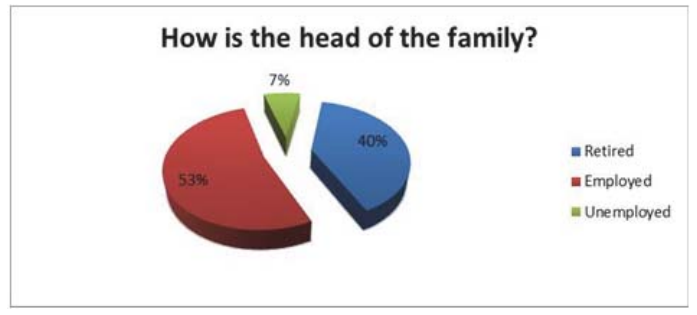

Question: Which of the family member is a migrant worker? In $63,6 \%$ of the cases it was the son or the daughter of the family. It was the head of the family in $24,5 \%$ of the cases. In $15.5 \%$ of the cases it was the brother or the sister and only in $3.6 \%$ of the cases the migrant worker was the wife of the head of the family. 


\section{Graphics 7.}

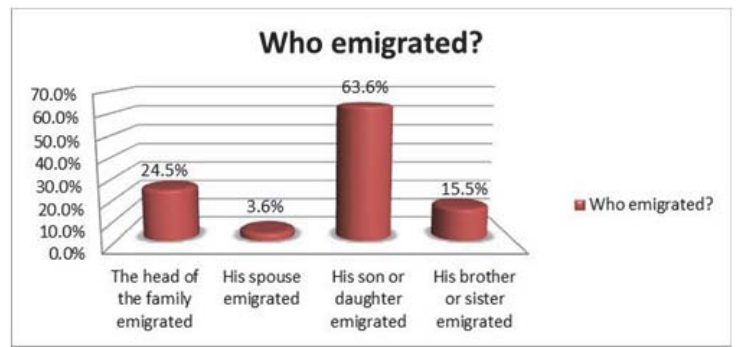

\section{The Remittance Transfer}

Processing the answers to the questions of the survey we conclude that an increased consciousness on the legal ways of remittance transfers does exist. Anyway our migrant workers still prefer the traditional ways i.e. the personal transfers of the remittances.

The answer to the question: Which means do you prefer to transfer your remittances: bank, OTP, personal transport(PT), as well as bank and PT, bank and OTP,OTP and PT almost 34.5\% of them used PT quite a high figure, thus complicating the correct assessment of the quantity of the remittances entering Albania. 20\% use OTP and PT and only $19 \%$ the banks and $15 \%$ banks and PT, thus in $65 \%$ of the cases we have a usage of PT in one way or another.

\section{Graphics 8.}

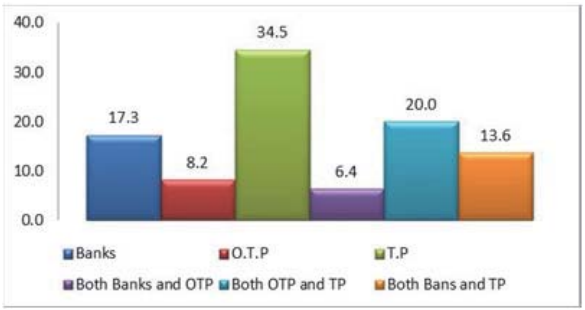

This choice made us suspect that the migrant workers had no personal accounts. That's why our next question was : Have you got a bank account?

Almost $58 \%$ of them gave a positive answer, yet only $17.3 \%$ of them use banks for their remittance transfers. Thus we understand that the lack of a bank account is not the main reason, why our migrant workers do not use banks for their remittance transfers.

\section{Graphics 9.}

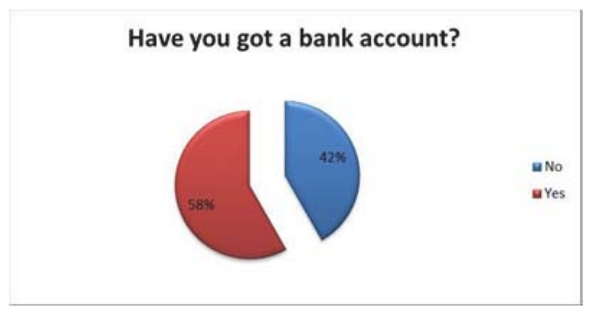

Then we asked another question; Do you know all the ways how to transfer your remittances?65,5\% of them answered yes, while $34,5 \%$ answered no. Even ignorance was not the main reason why our migrant workers avoid banks in their remittance transfers. 


\section{Graphics 10.}

\section{Do you know all the methods of remittance} transfers?

aNo $₫$ Yes

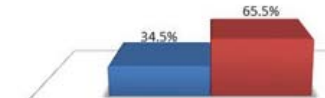

Then we questioned them: Why do you prefer personal transport? $70 \%$ of them answered: It is safer. This means our migrants are not aware of the safety of bank transfers. 57,3\% of them answered that PT is more rapid and $40 \%$ answered: It is cheaper. The last answer is an indication of the effect of the crises i.e. being inexpensive is an important factor in choosing the means and ways of money transfers.

\section{Graphics 11.}

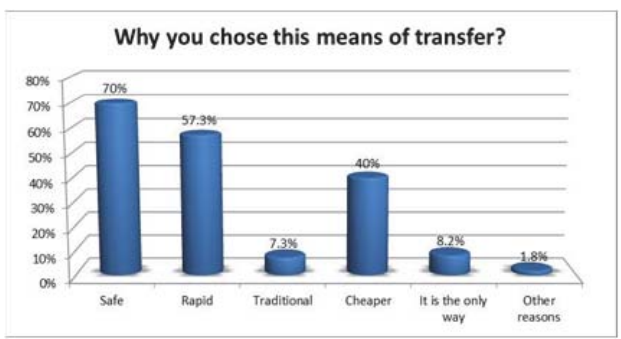

$47,3 \%$ of those questioned receive remittances once a month, while $52.7 \%$ of them once in 3 or six months or even once a year.

\section{Graphics 12}

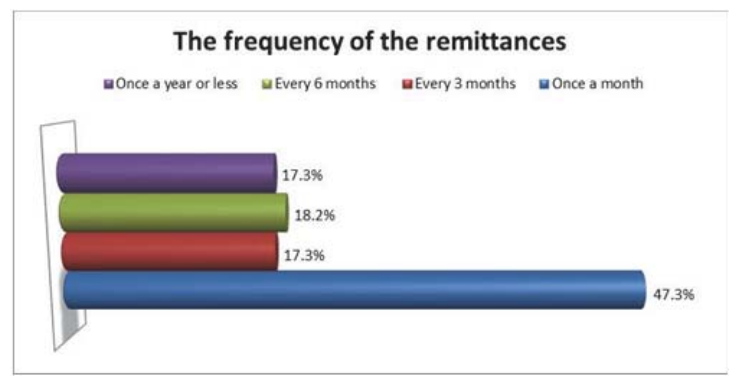

The question: What time do you receive the remittances was answered: in summer and during the holidays by $40 \%$ of those questioned while $60 \%$ of them answered they receive the money on regular bases.

\section{Graphics 13.}

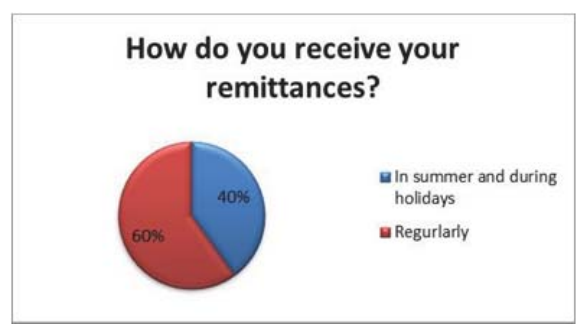




\section{The Remittances}

In order to receive more info on the e importance of remittances regarding the family budget we asked the following questions:

What are your monthly earnings, remittances included? What is the percentage of this earning covered by remittances from the beloved ones abroad? How much of the remittance money is used to cover the daily budget, the children education, for business, for savings, construction, electrical appliances etc?

The question: What are your monthly earnings was answered like this: 29\% gave 100 to 400 Euro monthly, 24\% 400 to 600 Euro monthly, $21 \%$ from 600 to 800 Euro monthly and 15\% from 800 to 1000 Euro monthly.

Almost $21 \%$ of them earn more than 1000 Euro. This figures show the influence of the global economic crises on the family earnings. Almost $80 \%$ of them enjoy average earnings, with some 100 to 800 Euro monthly, taking into account that almost $60 \%$ of the families consist of 4 to 5 members. Only $12 \%$ of those interviewed enjoy over 1200 Euro earnings monthly. That's why these families rely on remittance money to make a living.

\section{Graphics 14.}

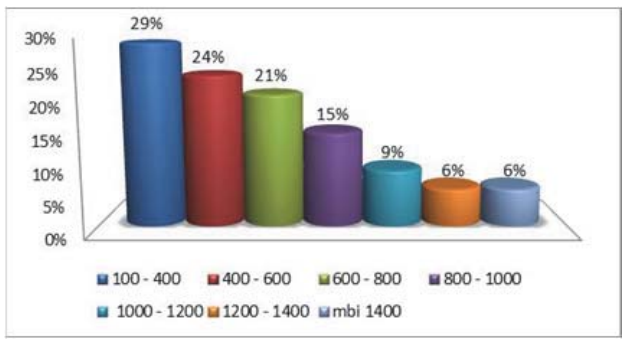

The question: What is the monthly amount of remittance you are receiving? It was answered 100 to 200 Euro monthly by $39,1 \%$ of the interviewed persons. $21 \%$ of them receive 200 to 400 Euro monthly and $24 \%$ of them receive 400 to 600 Euro monthly. Some $84 \%$ of them receive up to 600 Euro monthly. This shows that though two decades passed still remittances constitute an important component of the monthly earnings of these families. Lately we observe a remittance shrinking due to economic crises more than the family reunions(the famous remittance cycle)

Graphics 15 . What is the \% of the earnings covered by remittances?

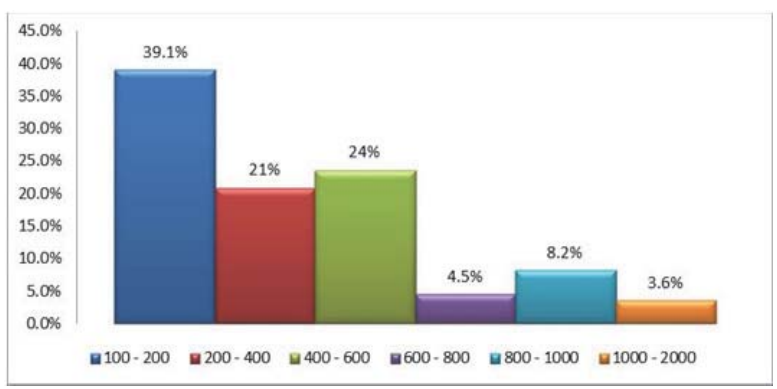

The following graphics reflects the frequency of the main usage of the remittance money. Almost $85 \%$ of the families use wholly or partially the remittance money for the daily sustenance. This is evidence of the difficult situation of the earnings in the Albanian families. This shows the earnings in the Albanian families are in a corner. A top percentage of the families use remittances to cover their children education, $59 \%$, and $65 \%$ of them for savings. Only a small percentage uses the remittance for construction 15\%and $13 \%$ use the remittance for business. This is the result of several causes such as family reunion, low family earnings, unsafe investment environment etc. 


\section{Graphics 16.}

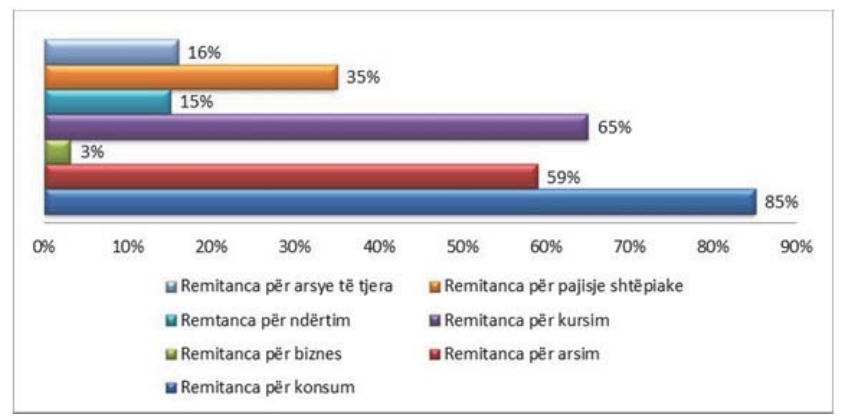

The above graphics show that migration and remittances still play a positive role in children's education. A study by UNICEF in 2009 measures the influence of migration and remittances on the children's education on two directions;

1. The usage of a part of the remittances to cover education expenses.

2. Their satisfaction from the education

Our questionnaire covers only the first direction. We witness a widespread usage of remittances for education purposes $(59 \%$ of them).

$65 \%$ of the families at least up to a certain extend use the remittance to increase family savings. Precisely such savings influence the migrants families but also the economy of the whole country, though we witness a downward trend in the recent years.

\section{Savings}

A part of our questionnaire dealt with the role of the remittances in family savings as well as their trend.

There was a marked fall in the savings of the migrant families, a fall in their standard of living and an increase in the cost of living. This forces the majority of the migrant families to have slimmer possibilities to save money. Let us consult the figures offered by our questionnaire.

Almost $60 \%$ of those questioned save up to 100 Euros monthly, a fact which supports our conclusions stated above. Only a fraction of these $60 \%$ saves 100 Euro monthly, the others save even less. $34,5 \%$ of those interviewed saved 100 to 500 Euro monthly, while only 6,4\% save more than 500 Euros. The last figure is quite small compared to the other two groups.

\section{Graphics 17.}

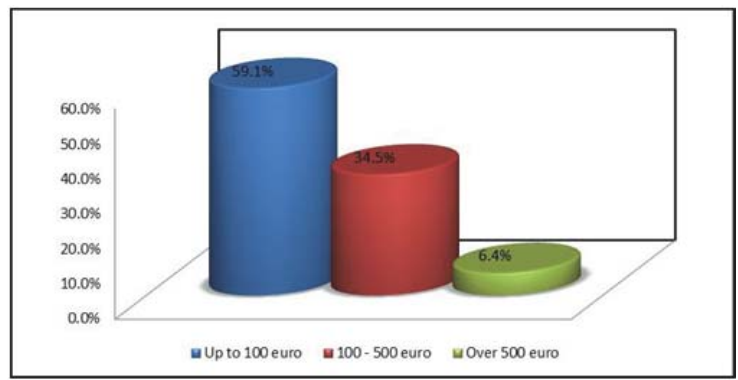

We interviewed families of the migrant workers concluding that there are two sources to obtain such savings respectively: money earned by the family in Albania and remittance money coming from their beloved ones working abroad.. In order to define the position of the remittances in these savings we asked the question: The savings are a result of the family earnings, or the remittances, or both of them? Almost $60 \%$ of the families have their savings because of the remittances. This is another piece of evidence of the importance of the remittances to the Albanian families and the Albanian economy 
in general. 37,35 of the families draw their savings from both remittances and family earnings. In this case also a certain percentage of the savings is due to remittances, too.

Only $3,6 \%$ of the families declare that their savings are fruit of only of their family earnings.

\section{Graphics 18.}

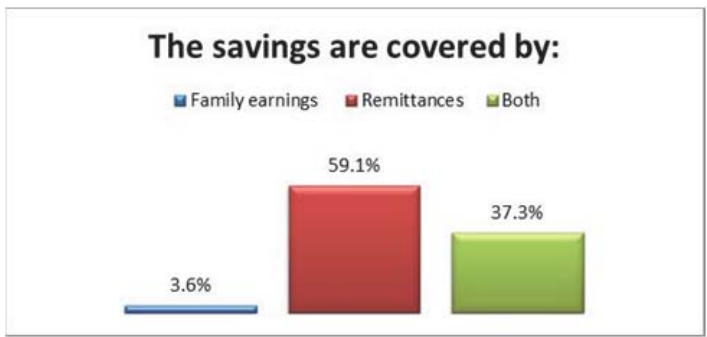

In order to understand what is the part of the family savings covered by the remittances in case when these savings resulted from the family earnings and also from the remittances, we asked this question: What part of your savings results from remittances? $60 \%$ of the families declared up to 100 Euro monthly. Taking into account that some $60 \%$ of the interviewed declared savings up to 100 Euro monthly and 34\% of them from 100 to 500 Euro monthly, it results that the remittances in most of them cover $70 \%$ of the savings. This figure shows the importance of the remittances to the savings of the Albanian families.

\section{Graphics 19.}

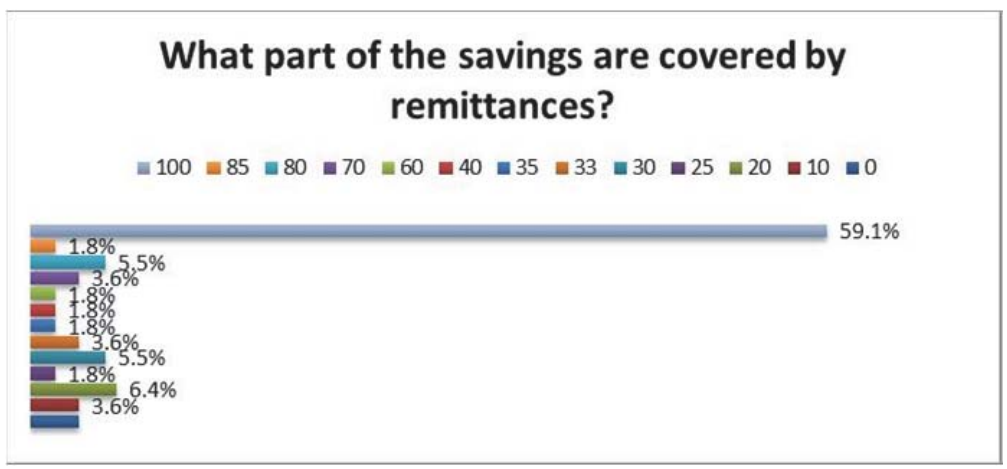

Most of the interviewed persons kept their savings at home, only 30\% used the banks. The main reasons for such a choice are;

a) Lack of a bank account, almost $42 \%$ of them.

b) The small amount of the savings and the fact that in case of emergency needs it takes time to withdraw your savings from the banks.

c) The money is safer at home and it is not worth putting it in a bank because of the bank interest for such sums of money is quite meager.

The next question in our questionnaire adds more arguments to that conclusion. Our question is :

What do you use your savings for? Retirement, education, daily usage, emergencies, construction, investments? Almost $52,7 \%$ of them use the savings as retirement money, $32 \%$ for construction, $25,5 \%$ for investments and $20,9 \%$ for children's education.

Quite a high percentage, 52,7\% use them for retirement, that's why they do not keep them in banks. Another important goal is children's education, while some $20,9 \%$ use the savings from the remittances for covering the consumption.

$58 \%$ of those interviewed use the savings for investments and in construction. This figure shows the importance of the remittances to our country's economy, compared to FDI. Remittances in this case are a sui generis type of FDI. 


\section{Graphics 20.}

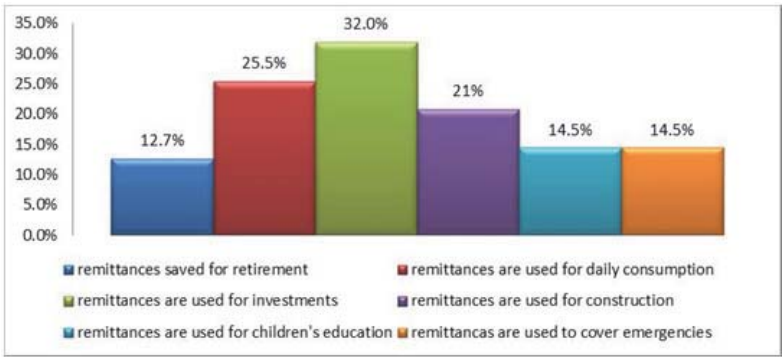

A relatively small number of families use the savings from remittances for construction and investments, naturally a question arises :Is the money saved sufficient to fulfill such goals? Only $34 \%$ of them admit that the saved money is insufficient and there is a need for additional money. $66 \%$ declare that they need no additional money for their investments. This is an indication of the fact of the lack of serious (big) investments as most of these families have invested their money in small and very small family businesses.

Anyway they offer also other reasons for not seeking additional capital. Such reasons are the insecurity and sometimes too much red tape in the banking system. The insecurity in the continues flow of the remittances due to the economic global crises. This insecurity makes the family entrepreneurs cautious, taking only small steps or adopting a wait and see attitude. The low wages, the shrinking remittances due to the economic crises are other reasons for the savings not being enough to cover the intended investments.

The global economic crises, which is present in most of the answers given to the question of our survey, is behind almost every reason for lack of investments, thus coupling the evidence from field work level to the data and figures of the annual reports of the Bank of Albania ,and other institutions like INSTAT, EUROSTAT or the World Bank.

\section{Conslusions}

D The trend of the remittances to Albania is an upward one till 2007 and a downward one up to now. The investments of the life savings of the migrants returning home for good is a temporary phenomenon. The increase in exports due to temporary causes such as rainy weather for the export of renewable energy, or favorable prices on the international market for chief Albanian export goods such as mineral ores.

$>$ The factors influencing the lowering of the remittances include;

1. Economic crises

2. Wage lowering and job insecurity also as a result of the crises

3. Higher education cost for their children

4. Family reunification thus no family member remaining in Albania

5. Weaker links between migrants and their relatives in Albania

\section{Recommendations}

We strongly recommend that the

* Albanian economy should find a new ways and means to make up for lost remittance money. Borrowing recklessly, or reducing consumptions and imports are not a way out.

* Increasing and diversifying exports aiming at an export orientated economy model of development

- Luring more tourists especially elite ones

* Changing the backward Albanian agriculture into a source of revenue and hard currency through exports

\section{References}

Banka e Shqipërisë, J. 2012 . Raporti i Politikës Monetare për tremujorin e Katërt të vitit 2011. 25.01.201

Gedeshi, I. 2002. Roli I remitancave nga emigrantët shqiptarë dhe ndikimi i tyre në ekonominë e vendit. Western Europe Economics, Vol. 40, No. 5 September-October 
INSTAT, Preliminary results of the Population and Housing Census 2001

IOM. 2005. Konkurenca për remitancat.Lidha e emigracionit të shqiptarëve me zhvillimin e Shqipërisë. Workshop Report. Tirana, $22^{\text {nd }}$ November 2005

Merita, B. J.2012. Analizë e zhvillimeve në Sektorin e Jashtëm të Ekonomisë Banka e Shqipërisë, Janar 2012

Moreno- Fontes Chanmartin, G. and Cantú- Bazaldúa, F. 2005. Identifikimi i potencialit për rritjen e investimeve prodhuese dhe pënësimit në Shqipëri,Moldavi dhe Ukrahinë të bazuar te remitancat. International Migration Paper, Social Protection Sector. ILO Geneva

Thanasi T. "Statistics on tougher times and shrinking remittances from Albanian migrants in Italy"

Thomas, K. 2007. Rritja e ndikimit të remitancave të migrantëve në Shqipëri. Studimi i IOM dhe ILO, Gjenevë , Mars 2007

Triandafyllous, A. 2011. Migrant Livelihoods the Greek crisis. ELIAMEP, Athens

Zolberg A., The next wawes: Migration theory for a changing world, International Migration Reviews, 1989, 23 (3). 
